\title{
THE REGULATORY ROLE OF PERIPHERAL BLOOD MONONUCLEAR CELL FUNCTION BY A20
}

\author{
Nguyen Thi Xuan ${ }^{1,2, \bowtie}$, Nguyen Huy Hoang ${ }^{1,2}$ \\ ${ }^{I}$ Institute of Genome Research, Vietnam Academy of Science and Technology \\ ${ }^{2}$ Graduate University of Science and Technology, Vietnam Academy of Science and Technology \\ ${ }^{\circledR}$ To whom correspondence should be addressed. E-mail: xuannt@igr.ac.vn
}

Received: 11.10.2019

Accepted: 17.12.2019

SUMMARY

Peripheral blood mononuclear cells (PBMC) consist of lymphocytes (T cells, B cells, natural killer cells), monocytes and dendritic cells and play important roles in initiating and regulating immunity against pathogens or immunotolerance to allergens. Activation of PBMCs is induced upon exposure to multiple stimuli by the binding with toll-like receptors (TLRs), recognition elements of the innate immune system. A20 is a negative regulator of nuclear factor (NF)- $\mathrm{BB}$-dependent immune reaction in response to TLR ligands. A20-deficient mice display severe inflammation, tissue damage in multiple organs, cachexia and premature mortality. Single nucleotide polymorphisms (SNPs) at $A 20$ gene region in humans reduce the binding capacity of A20 to NF- $\kappa B$ subunits, resulting in reduced expression and function of A20 and leading to the pathogenesis of autoimmune and cancers. Although the inhibitory role of A20 on immune cells including B, T and DC functions has been previously reported, the effect of A20 on PBMC function is not mentioned yet. The present study, therefore, explored whether $A 20$ expression is involved in immunophenotypic changes, the release of cytokine production, cell migration, and apoptosis. To this end, immonophenotypic profile and cell apoptosis were examined by flow cytometry, secretion of inflammatory cytokines by ELISA and cell migration by a transwell migration assay. As a result, percentages of $\mathrm{CD}^{+} \mathrm{CD} 25^{+}, \mathrm{CD} 19^{+} \mathrm{CD} 25^{+}$, and $\mathrm{CD} 11 \mathrm{~b}^{+} \mathrm{CD} 40^{+}$ expressing cells, the release of TNF- $\alpha$ and IL- $1 \beta$ and cell migration were enhanced in $A 20$-silenced PBMCs. However, cell apoptosis was independent of the presence of $A 20$ in PBMCs. In conclusion, these results attained in this study suggested that $A 20$ expression might modulate the immune response in autoimmune disease and cancers.

Keywords: A20, apoptosis, cytokine, migration and PBMCs

\section{INTRODUCTION}

A20 gene encodes a 790-amino acid zinc finger protein and is considered as a negative regulator of

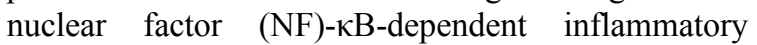
reaction in response to lipopolysaccharide (LPS), inflammatory cytokines including TNF- $\alpha$ (Wang et al., 2013) and several other stimuli. In mice, $A 20$ deficiency leads to immune hyper-activation and $A 20$ deficient mice display severe inflammation, tissue damage in multiple organs, cachexia and premature mortality (Lee et al., 2000). Mice lacking A20 in DCs fail to LPS tolerance and die within 6 hours by a cytokine storm (Xuan et al., 2014). In humans, A20 participates in protecting cell injury and suppressing pro-inflammatory cytokine secretion in several autoimmune diseases (Sun et al., 2019; Zhou et al.,
2016). Recent studies implicated that single nucleotide polymorphisms (SNPs) at $A 20$ gene region in humans reduce the binding capacity of A20 to NF- $\kappa \mathrm{B}$ subunits, resulting in reduced expression and function of A20 (Catrysse et al., 2014).

Peripheral blood mononuclear cells (PBMCs) are immune cells including lymphocytes (T cells, B cells, natural killer cells), monocytes and dendritic cells, which play important roles in initiating and regulating immunity against pathogens or immune tolerance to allergens (Lauer et al., 2019; Simader et al., 2019). Activation of PBMCs is induced upon exposure to multiple stimuli by the binding with tolllike receptors (TLRs), recognition elements of the innate immune system (Simader et al., 2019). A TLR4 ligand, LPS is one of the most potent 
activators and derived from microbial to activate intracellular signal transductions, resulting in enhanced transcripts of target genes such as inflammatory cytokines and cell surface markers on immune cells (Hovelmeyer et al., 2011). The promoting role on the inflammatory reaction by TLR ligands is modulated by different functional genes and whose expression levels are determinants for a response skewed towards immunity or tolerance as well as cell physiological properties including cell migration and apoptosis (Lauer et al., 2019; Simader et al., 2019).

The cell migration is characterized by binding between chemokine receptors on the cell surface to specific ligands expressed on epithelial cells in lymphoid organs. A20 has been shown to inhibit the migration of cancer cells mediated through activation of $\mathrm{NF}-\kappa \mathrm{B}$ and signal transducer and activator of transcription (STAT) signalings (Chen et al., 2018; Duy et al., 2019). In order to maintain tissue homeostasis, the immune cells eventually undergo cell apoptosis, which is identified by activation of caspases and exposure of phosphatidylserine (PS) on the external leaflet of the plasma membrane. PS exposure is frequently detected by the binding of annexin $\mathrm{V}$. Recent studies indicated that A20 plays a role as an inhibitor of cell death in hepatocytes (Li et al., 2019) and myeloidderived suppressor cells (Shao et al., 2015).

Although the inhibitory role of A20 on immune cells including $\mathrm{B}, \mathrm{T}$ and $\mathrm{DC}$ functions has been previously reported, the effect of A20 on PBMC function is not mentioned yet. The present study has thus been conducted to determine changes in immunophenotype, cytokine production, migration and apoptosis of PBMCs treated with A20 small interfering RNA (siRNA).

\section{MATERIALS AND METHODS}

\section{Isolation of PBMCs}

PBMCs from whole blood samples of healthy donors were collected by venipuncture and transferred to sterile tubes containing EDTA as an anticoagulant. The cells were isolated via density gradient centrifugation (Ficoll-Paque Plus, GE Healthcare Life Sciences) using Hank's buffer (Gibco). Freshly isolated PBMCs were obtained by centrifuging at $400 \mathrm{~g}$ for $30 \mathrm{~min}$ at room temperature. The cells were counted in a Neubauer chamber and washed with PBS, the final cell pellet was resuspended and cultured in RPMI 1640 medium
(Gibco) with 10\% FBS, L-glutamine (Gibco), Antibiotic-Antimycotic Solution (Sigma), and MEM NEAA (Gibco) at a density of $2 \times 10^{6}$ cells $/ \mathrm{ml}$. The cells then were treated with or without lipopolysaccharide (LPS) from Escherichia coli (1 $\mu \mathrm{g} / \mathrm{mL}$, Sigma)

\section{Transfection of PBMCs with siRNA}

Human A20-targeted and control siRNAs (predesigned siRNA, Thermo Scientific) were transfected into PBMCs $\left(2 \times 10^{6}\right.$ cells $\left./ \mathrm{mL}\right)$ with the help of Lipofectamine RNAiMAX Reagent (Invitrogen) according to the manufacturer's recommendations. Cells were incubated for $48 \mathrm{~h}$ at $37^{\circ} \mathrm{C}, 5 \% \mathrm{CO}_{2}$. After washing three times with PBS, the cells were used for further experiments.

\section{Immunostaining and flow cytometry}

Immunophenotype of PBMCs were determined by flow cytometry (FACSAria Fusion, BD Biosciences) as described elsewhere (Wang et al., 2013). Cells $\left(5 \times 10^{6}\right)$ were incubated in $100 \mu \mathrm{L}$ FACS buffer (PBS plus $0.1 \%$ FCS) containing fluorochrome-coupled antibodies to CD45, CD19, CD3, CD4, CD8 a, CD11b, CD25, CD40, CD44 and CD86 (all from eBioscience) at a concentration of 10 $\mu \mathrm{g} / \mathrm{mL}$. After incubating with the antibodies for 60 min at $4^{\circ} \mathrm{C}$, the cells were washed twice and resuspended in FACS buffer for flow cytometry analysis.

\section{Cytokine quantification}

Cell supernatant was collected from the cell culture and stored at $-20^{\circ} \mathrm{C}$ until use for ELISA. TNF- $\alpha$, IL-12p70, IL- 6 and IL-1 $\beta$ concentrations were determined by using ELISA kits (eBioscience) according to the manufacturer's protocol.

\section{DC migration assay}

PBMCs were washed twice with PBS and suspended in RPMI 1640 medium. Migration was assessed in triplicate in a multiwell chamber with a pore diameter size of $3 \mu \mathrm{m}$ (BD Falcon). The cell suspension $\left(2 \times 10^{6}\right.$ cells $\left./ \mathrm{ml}\right)$ was placed in the upper chamber to migrate into the lower chamber in which either CCL19 (250 ng/mL, PeproTech) or medium alone as a control for spontaneous migration were included. The chamber was placed in a $5 \% \mathrm{CO}_{2}$, $37^{\circ} \mathrm{C}$ incubator for $24 \mathrm{~h}$. The cells that migrated into the lower chamber were collected and counted under a light microscope using Trypan blue. The mean number of spontaneously migrated cells were 
subtracted from the total number of migrated cell and migration was considered by calculating the percentage of migrating cell related to the input.

\section{Caspase 3 activity assay}

Caspase 3 activity was determined using kits from Biovision according to the manufacturer's instructions. Briefly $5 \times 10^{6}$ cells were washed twice with cold PBS, fixed and permeabilized with 'Cytofix/Cytoperm' solution and then by washing twice with 'Perm/ Wash' buffer. Then cells were stained with FITC conjugated anti-active caspase 3 antibody in 'Perm/ Wash' buffer for 60 minutes. After 2 washing steps, the cells were analysed by flow cytometry.

\section{Phosphatidylserine translocation}

Apoptotic cell membrane scrambling was evidenced from annexin $\mathrm{V}$ binding to PS at the cell surface. The percentage of PS-translocating cells was evaluated by staining with FITC-conjugated Annexin V. In brief, $2 \times 10^{6}$ cells were harvested and washed twice with annexin washing buffer (AWB, $10 \mathrm{mM}$ Hepes/NaOH, pH 7.4, $140 \mathrm{mM} \mathrm{NaCl}, 5 \mathrm{mM} \mathrm{CaCl} 2$ ). The cell pellet was resuspended in $100 \mu \mathrm{L}$ of annexinV-Fluos labelling solution (Roche) $(20 \mu \mathrm{L}$ Annexin-VFluos labelling reagent in $1 \mathrm{~mL}$ AWB), incubated for
$15 \mathrm{~min}$ at room temperature. After washing with AWB, they were analysed by flow cytometry.

\section{Statistics}

Data are provided as means $\pm \mathrm{SEM}, n$ represents the number of independent experiments. Differences were tested for significance using Student's unpaired two-tailed $t$-test or ANOVA in SPSS software, as appropriate. $P<0.05$ was considered statistically significant.

\section{RESULTS}

\section{Immunophenotypic profile in $A 20$-silenced PBMCs}

A20 is previously shown to negatively modulate the NF- $\kappa \mathrm{B}$-mediated function of immune cells such as dendritic cells and B cells (Hovelmeyer et al., 2011; Xuan et al., 2014). Analysis of cell surface marker expression was conducted to evaluate the effect of A20 on specific immune cell populations. The cells were transfected with control or $A 20$ siRNA for $48 \mathrm{~h}$ and followed by treatment of the cells without or with LPS for another $24 \mathrm{~h}$. The protein level of A20 was observed to be downregulated in A20-silenced PBMCs (Figure 1A).

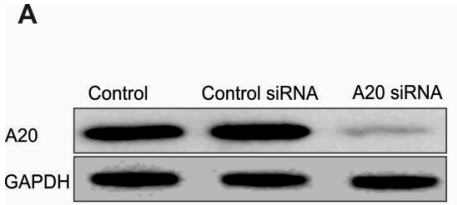

C

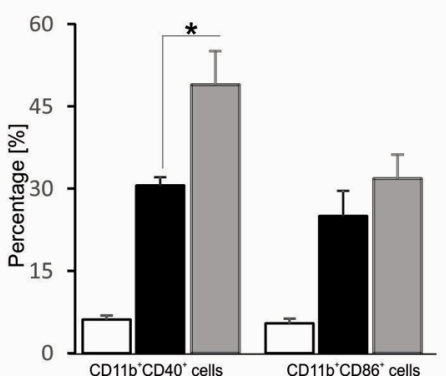

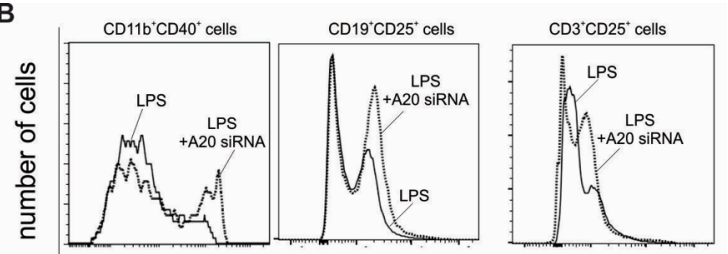

Relative fluorescence units

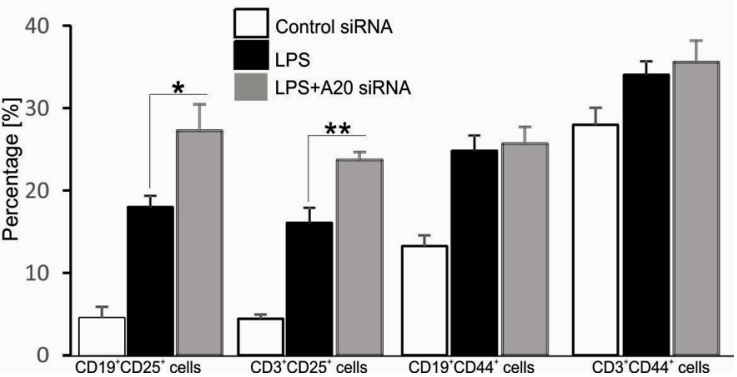

Figure 1. Immunophenotypic profile of A20-silenced PBMCs. A. Original Western blot of PBMCs, which were untreated or treated with control or $A 20$ siRNAs. Protein extracts were analysed by direct western blotting using antibody directed against A20 and GAPDH. B. Representative FACS histograms depicting CD $11 \mathrm{~b}^{+} \mathrm{CD} 40^{+}, \mathrm{CD}^{+} \mathrm{CD} 25^{+}$and $\mathrm{CD} 19^{+} \mathrm{CD} 25^{+}$expressing cells, which were treated with LPS in the absence or presence of $A 20$ siRNA. C. Arithmetic mean $\pm S E M(n=6)$ of percentages of $\mathrm{CD} 11 \mathrm{~b}^{+} \mathrm{CD} 40^{+}, \mathrm{CD} 11 \mathrm{~b}^{+} \mathrm{CD} 86^{+}, \mathrm{CD} 19^{+} \mathrm{CD} 25^{+}, \mathrm{CD} 3^{+} \mathrm{CD} 25^{+}, \mathrm{CD} 19^{+} \mathrm{CD} 44^{+}$and $\mathrm{CD} 3^{+} \mathrm{CD} 44^{+}$expressing cells are shown to untreated (control, white bars) and LPS-treated PBMCs in the absence (black bars) or presence (grey bars) of A20 siRNA. All samples were gated with $\mathrm{CD}_{4} 5^{+}$live cells. ${ }^{*}(p<0.05)$ and ${ }^{* *}(p<0.01)$ indicate significant differences between LPS-treated groups (ANOVA). 
For the determination of immunophenotypes, the $\mathrm{CD} 5^{+}$gated population was analyzed for percentages and activation of PBMCs. Results revealed that LPS treatment results in activation of myeloid, $\mathrm{T}$ and $\mathrm{B}$ cells (Figure 1B-C) and downregulation of A20 by using $A 20$ siRNA further enhanced the proportion of $\mathrm{CD} 11 \mathrm{~b}^{+} \mathrm{CD} 40^{+}$(activated myeloid cells), $\mathrm{CD} 19^{+} \mathrm{CD} 25^{+}$(activated B cells) and $\mathrm{CD}^{+} \mathrm{CD}^{2} 5^{+}$(activated $\mathrm{T}$ cells) expressing cells,

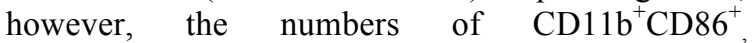
$\mathrm{CD} 19^{+} \mathrm{CD} 44^{+}$and $\mathrm{CD}_{3}^{+} \mathrm{CD} 44^{+}$cells were similar to control group (Figure 1B-C). The evidence suggested that A20 partially inhibited activation of myeloid, T and B cell populations.

\section{Role of A20 in regulating cytokine productions by PBMCs}

We next examined cytokine productions secreted by LPS-induced PBMCs. LPS treatment leads to increased release of inflammatory cytokines by PBMCs, however, A20-silenced mature PBMCs produced higher TNF- $\alpha$ and IL- $1 \beta$ cytokines as compared to control siRNA-treated PBMCs (Figure 2 ), pointing out that the release of TNF- $\alpha$ and IL- $1 \beta$ was sensitive to the presence of $A 20$ in PBMCs.
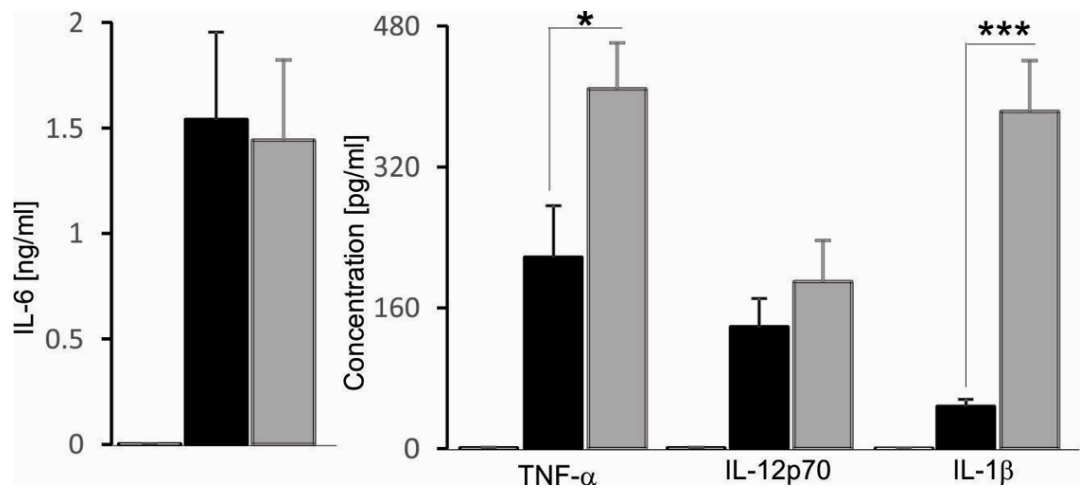

Figure 2. Release of cytokines in A20-silenced PBMCs. Arithmetic means \pm SEM $(n=6)$ of IL-6, IL-12p70, TNF- $\alpha$ and IL-1 $\beta$ concentrations were attained from supernatants of untreated (control, white bars) and LPS-treated PBMCs in the absence (black bars) or presence (grey bars) of A20 siRNA. ${ }^{*}(p<0.05)$ and ${ }^{* * *}(p<0.001)$ indicate significant differences between LPS-treated groups (ANOVA).

Role of A20 in regulating PBMC migration

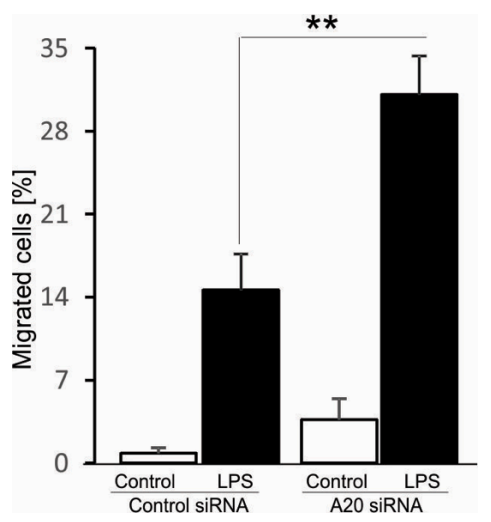

Figure 3. Effect of $A 20$ on the migration of PBMCs. Arithmetic means \pm SEM $(n=6)$ of percentages of migrated PBMCs, which were untreated (control) or treated with LPS in the absence or presence of $A 20$ siRNA. ${ }^{* *}(p<0.01)$ indicates a significant difference between LPS-treated groups (ANOVA).
In addition of regulating immune responses by secretion of various cytokines, cell migration is also a functional hallmark of activated PBMCs. With regard to the inhibitory effect of A20 on functional maturation of PBMCs, the migration of $A 20$-silenced PBMCs was increased compared to control siRNAtreated PBMCs (Figure 3).

\section{Role of A20 in regulating PBMC apoptosis}

Finally, cell viability was checked by measuring annexin $\mathrm{V}$ binding to the cell membrane and caspase 3 activity. As shown in Figure 4 that LPS protects PBMCs against suicidal cell death, as percentages of annexin $\mathrm{V}^{+}$and caspase $3^{+}$PBMCs were reduced when treated with LPS. The effects were remained unaltered in the presence of $A 20$ siRNA, pointing out that the presence of $A 20$ was not sensitive to apoptotic signaling in PBMCs. 

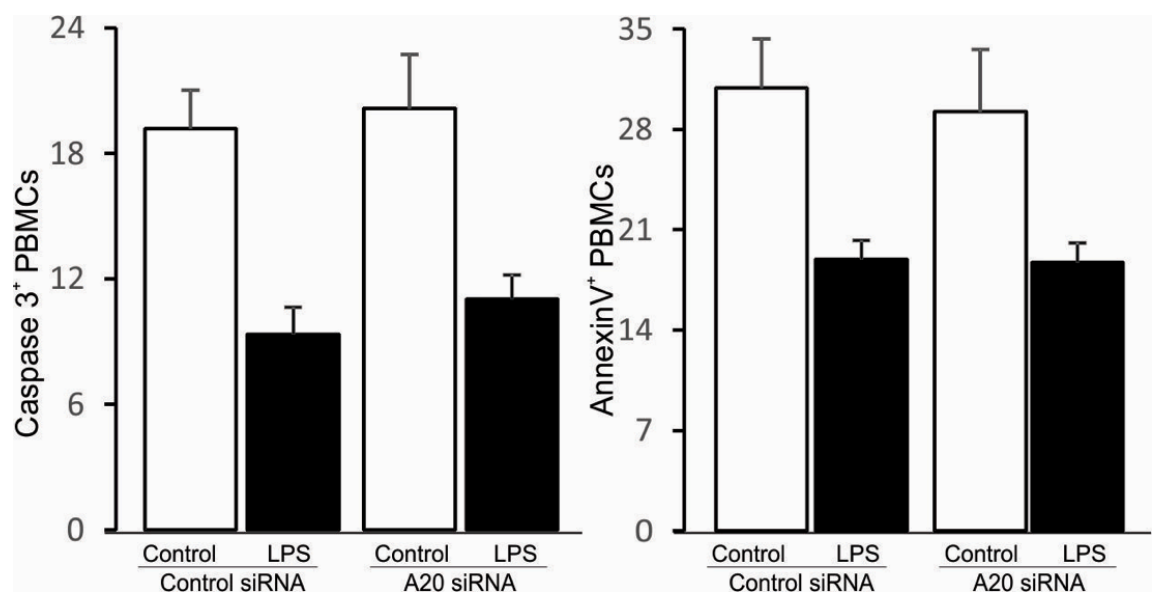

Figure 4. Effect of $A 20$ on apoptosis of PBMCs. Arithmetic mean \pm SEM $(n=6)$ of percentages of caspase $3^{+}$and annexin $V^{+}$ expressing PBMCs, which were either treated with control siRNA or A20 siRNA in the presence or absence of LPS.

\section{DISCUSSION}

Although it is well known that A20 participates in inhibiting functional activation of several immune cells including dendritic, $\mathrm{T}$ and $\mathrm{B}$ cells (Duy et al., 2019; Hovelmeyer et al., 2011), the effect of A20 on PBMC function is not mentioned yet. In addition to the presence of dendritic, T and B cells, PBMCs also comprise of other cell types such as myeloid, NK cells and monocytes. Moreover, the association among cell percentages and their activation expression indeed needs to be further analysed to determine the functional role of each cell type in the PBMC population. Accordingly, we observed that lack of $A 20$ expression on PBMCs resulted in increased expression of CD25 on B and T cells and a higher amount of CD40 on myeloid cells as well as enhanced the release of the inflammatory cytokines of TNF- $\alpha$ and IL-1 $\beta$. Our previous study (Xuan et al., 2014) shows that A20 inhibits expression of CD40, which is expressed on B cells and ligation of CD40 with CD40L to stimulate B cell proliferation and activation (Luczynski et al., 2006), therefore increased expression of CD40 on myeloid cells might lead to recruitment of activated $B$ cells into host blood. In an unpublished investigation, we also showed a direct association between $\mathrm{CD} 11 \mathrm{~b}^{+} \mathrm{CD} 40^{+}$ and $\mathrm{CD} 19^{+} \mathrm{CD} 25^{+}$expressing cells in acute lymphoblastic leukemia. In addition, mice lacking A20 in $\mathrm{T}$ cells display the augmented number of $\mathrm{CD} 25^{+} \mathrm{T}$ cells (Fischer et al., 2017) and inactivation of A20 is involved in the pathogenesis of various B cell lymphomas (Kato et al., 2009; Shembade, Harhaj, 2012). Therefore, the inhibitory effect of
A20 on the activated expression of PBMCs could link to dysregulation of immune cells in patients with leukemia.

Other studies additionally revealed the regulatory role of A20 on the physiological function of immune cells such as cell migration and apoptosis (Chen et al., 2018; Hovelmeyer et al., 2011; Xuan et al., 2015). Similarly, we used LPS as a positive control for cell migration and observed that cell migration was enhanced in $A 20$-silenced PBMCs as compared to control cells. Cell migration is one of the essential steps for the metastasis of cancer cells. For the determination of involvement of cell apoptosis, no research on immune cells investigated the role of A20 in modulating cell death yet. In this study, we showed that the silencing of $A 20$ did not affect PBMC apoptosis. However, other studies on cancer cells or other cell types reported that A20 inhibits apoptosis of hepatocytes (Li et al., 2019), myeloid-derived suppressor cells (Shao et al., 2015) or several cancer cells (De Wilde et al., 2017; Johansson et al., 2016; Zhang et al., 2012).

In conclusion, the present study indicates that down-regulation of $A 20$ leads to increases in the partial activation of myeloid, $\mathrm{B}$ and $\mathrm{T}$ cells, the release of TNF- $\alpha$ and IL- $1 \beta$ and PBMC migration. However, the apoptosis of PBMCs is independent on the presence of $A 20$ in PBMCs. A20 expression level might modulate the immune response in autoimmune disease and cancers.

Acknowledgments: This research is funded by Vietnam National Foundation for Science and 
Technology Development (NAFOSTED) under grant number 108.06-2017.16

\section{REFERENCES}

Catrysse L, Vereecke L, Beyaert R, and van Loo G. (2014) A20 in inflammation and autoimmunity. Trends in Immunology 35: 22-31.

Chen L, Lei L, Li T, Yan J, and Jiang J. (2018) A20 alleviates the vascular remodeling induced by homocysteine. American Journal of Translational Research 10: 3991-4003.

De Wilde K, Martens A, Lambrecht S, Jacques P, Drennan MB, Debusschere K, Govindarajan S, Coudenys J, Verheugen E, Windels F, Catrysse L, Lories R, McGonagle D, Beyaert R, van Loo G, and Elewaut D. (2017) A20 inhibition of STAT1 expression in myeloid cells: a novel endogenous regulatory mechanism preventing development of enthesitis. Annals of the Rheumatic Diseases 76: 585-592.

Duy PN, Thuy NT, Trang BK, Giang NH, Van NTH, and Xuan NT. (2019) Regulation of NF-kappaB- and STAT1mediated plasmacytoid dendritic cell functions by A20. PLoS One 14: e0222697.

Fischer JC, Otten V, Kober M, Drees C, Rosenbaum M, Schmickl M, Heidegger S, Beyaert R, van Loo G, Li XC, Peschel C, Schmidt-Supprian M, Haas T, Spoerl S, and Poeck H. (2017) A20 Restrains Thymic Regulatory T Cell Development. The Journal of Immunology 199: 23562365.

Hovelmeyer N, Reissig S, Xuan NT, Adams-Quack P, Lukas D, Nikolaev A, Schluter D, and Waisman A. (2011) A20 deficiency in B cells enhances B-cell proliferation and results in the development of autoantibodies. European Journal of Immunology 41: 595-601.

Johansson P, Bergmann A, Rahmann S, Wohlers I, Scholtysik R, Przekopowitz M, Seifert M, Tschurtschenthaler G, Webersinke G, Jager U, Siebert R, Klein-Hitpass L, Duhrsen U, Durig J, and Kuppers R. (2016) Recurrent alterations of TNFAIP3 (A20) in T-cell large granular lymphocytic leukemia. International Journal of Cancer 138: 121-124.

Kato M, Sanada M, Kato I, Sato Y, Takita J, Takeuchi K, Niwa A, Chen Y, Nakazaki K, Nomoto J, Asakura Y, Muto S, Tamura A, Iio M, Akatsuka Y, Hayashi Y, Mori H, Igarashi T, Kurokawa M, Chiba S, Mori S, Ishikawa Y, Okamoto K, Tobinai K, Nakagama H, Nakahata T, Yoshino T, Kobayashi Y, and Ogawa S. (2009) Frequent inactivation of A20 in B-cell lymphomas. Nature 459: 712-716.

Lauer FT, Parvez F, Factor-Litvak P, Liu X, Santella RM, Islam T, Eunus M, Alam N, Hasan A, Rahman M, Ahsan H, Graziano J, and Burchiel SW. (2019) Changes in human peripheral blood mononuclear cell (HPBMC) populations and T-cell subsets associated with arsenic and polycyclic aromatic hydrocarbon exposures in a Bangladesh cohort. PLoS One 14: e220451.

Lee EG, Boone DL, Chai S, Libby SL, Chien M, Lodolce JP, and Ma A. (2000) Failure to regulate TNF-induced NFkappaB and cell death responses in A20-deficient mice. Science 289: 2350-2354.

Li KZ, Liao ZY, Li YX, Ming ZY, Zhong JH, Wu GB, Huang S, and Zhao YN. (2019) A20 rescues hepatocytes from apoptosis through the NF-kappaB signaling pathway in rats with acute liver failure. Bioscience Reports 39:

Luczynski W, Stasiak-Barmuta A, Ilendo E, KrawczukRybak M, Malinowska I, Mitura-Lesiuk M, Parfienczyk A, and Szymanski M. (2006) CD40 stimulation induces differentiation of acute lymphoblastic leukemia cells into dendritic cells. Acta Biochimica Polonica 53: 377-382.

Shao B, Wei X, Luo M, Yu J, Tong A, Ma X, Ye T, Deng H, Sang Y, Liang X, Ma Y, Wu Q, Du W, Du J, Gao X, Wen Y, Fu P, Shi H, Luo S, and Wei Y. (2015) Inhibition of A20 expression in tumor microenvironment exerts antitumor effect through inducing myeloid-derived suppressor cells apoptosis. Scientific Reports 5: 16437.

Shembade N, and Harhaj EW. (2012) Regulation of NFkappaB signaling by the A20 deubiquitinase. Cellular and Molecular Immunology 9: 123-130.

Simader E, Beer L, Laggner M, Vorstandlechner V, Gugerell A, Erb M, Kalinina P, Copic D, Moser D, Spittler A, Tschachler E, Jan Ankersmit H, and Mildner M. (2019) Tissue-regenerative potential of the secretome of gammairradiated peripheral blood mononuclear cells is mediated via TNFRSF1B-induced necroptosis. Cell Death and Disease 10: 729.

Wang X, Deckert M, Xuan NT, Nishanth G, Just S, Waisman A, Naumann M, and Schluter D. (2013) Astrocytic A20 ameliorates experimental autoimmune encephalomyelitis by inhibiting NF-kappaB- and STAT1dependent chemokine production in astrocytes. Acta Neuropathologica 126: 711-724.

Xuan NT, Wang X, Nishanth G, Waisman A, Borucki K, Isermann B, Naumann M, Deckert M, and Schluter D. (2015) A20 expression in dendritic cells protects mice from LPS-induced mortality. European Journal of Immunology 45: 818-828.

Zhang F, Yang L, and Li Y. (2012) The role of A20 in the pathogenesis of lymphocytic malignancy. Cancer Cell International 12: 44.

Zhou Q, Wang H, Schwartz DM, Stoffels M, Park YH, Zhang Y, Yang D, Demirkaya E, Takeuchi M, Tsai WL, Lyons JJ, Yu X, Ouyang C, Chen C, Chin DT, Zaal K, Chandrasekharappa SC, E PH, Yu Z, Mullikin JC, Hasni SA, Wertz IE, Ombrello AK, Stone DL, Hoffmann P, Jones A, Barham BK, Leavis HL, van Royen-Kerkof A, 
Sibley C, Batu ED, Gul A, Siegel RM, Boehm M, Milner JD, Ozen S, Gadina M, Chae J, Laxer RM, Kastner DL, and Aksentijevich I. (2016) Loss-of-function mutations in
TNFAIP3 leading to A20 haploinsufficiency cause an early-onset autoinflammatory disease. Nature Genetics 48 : $67-73$

\title{
VAI TRÒ ĐIỀU HÒA CHỨC NĂNG TẾ BÀO ĐƠN NHÂN MÁU NGOẠI VI CỦA A20
}

\author{
Nguyễn Thị Xuân ${ }^{1,2}$, Nguyễn Huy Hoàng ${ }^{1,2}$ \\ ${ }^{I}$ Viện Nghiên cưu hệ gen, Viện Hàn lâm Khoa học và Công nghệ Việt Nam \\ ${ }^{2}$ Hocc viện Khoa hoc và Công nghệ, Viện Hàn lâm Khoa học và Công nghệ Việt Nam
}

\section{TÓM TĂT}

Tế bào đơn nhân máu ngoại vi (PBMC) là tế bào tham gia điều hòa miễn dịch chống lại tác nhân gây bệnh và miễn dịch đối kháng chống lại tác nhân dị ứng. A20 là gen điều hòa ngược các phản ứng miễn dịch thông qua tín hiệu phân tử NF- $\mathrm{KB}$. Vai trò điều hòa chức năng tế bào $\mathrm{PBMC}$ của $\mathrm{A} 20$ chưa được nghiên cứu rộng rãi. Chính vì thế, nghiên cứu của chúng tôi đã phân tích ảnh hưởng của $\mathrm{A} 20$ đến kiểu hình miễn dịch, sự giải phóng các cytokine viêm, sự di cư và sự chết apoptosis trong tế bào PBMC. Trong nghiên cứu này, kiểu hình miễn dịch và sự chết apoptosis được xác định bằng kỹ thuật flow cytometry, sự tiết các cytokine gây viêm được đo bằng kỹ thuật ELISA và sự di cư của tế bào bằng phương pháp đếm tế bào di chuyển từ màng trên xuống dưới. Kết quả nhận được cho thấy, bất hoạt gen $\mathrm{A} 20$ trong tế bào PBMC làm tăng tỷ lệ tế bào dương tính với các marker $\mathrm{CD} 3^{+} \mathrm{CD} 25^{+}, \mathrm{CD} 19^{+} \mathrm{CD} 25^{+}$và $\mathrm{CD} 11 \mathrm{~b}^{+} \mathrm{CD} 40^{+}$, tăng sự giải phóng các cytokine $\mathrm{TNF}-\alpha$ và IL-1 $\beta$ và sự di cư tế bào nhiều hơn. Tuy nhiên, sự chết apoptosis của tế bào PBMC không bị ảnh hưởng bởi sự có mặt của gen $\mathrm{A} 20$. Kết quả nghiên cứu cho thấy gen $\mathrm{A} 20$ có thể tham gia điều hòa sự trả lời miễn dịch trong bệnh nhân tự miễn và ung thư.

Tù̀ khóa: A20, apoptosis, cytokine và tế bào đơn nhân máu ngoại vi. 